\title{
INDUCING EFFECT OF CHITOSAN ON THE PHYSIOLOGICAL AND BIOCHEMICAL INDICES OF EGGPLANT (SOLANUM MELONGENA L.) GENOTYPES UNDER HEAT AND HIGH IRRADIANCE
}

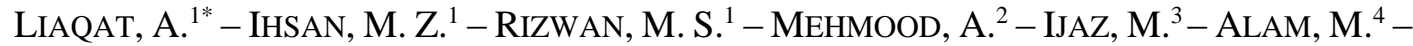 \\ ABDUllah, M. ${ }^{1}$ - WAJID, M. ${ }^{5}$ - HuSSAIN, R. ${ }^{6}$ - NAEEM, M. ${ }^{7}-$ YAQUB, M. S. ${ }^{6}$ \\ ${ }^{I}$ Cholistan Institute of Desert Studies (CIDS), The Islamia University of Bahawalpur, \\ Bahawalpur, Pakistan \\ ${ }^{2}$ Department of Agronomy, University of Agriculture, Faisalabad, Pakistan \\ ${ }^{3}$ College of Agriculture, Bahauddin Zakariya University, Bahadur sub Campus, Layyah, \\ Pakistan
}

\author{
${ }^{4}$ Department of Horticulture, The University of Agriculture, Peshawar, Pakistan \\ ${ }^{5}$ Plant Physiology Division, Nuclear Institute of Agriculture, Tandojam, Sindh, Pakistan \\ ${ }^{6}$ Department of Horticultural Sciences, UCA\&ES, The Islamia University of Bahawalpur, \\ Bahawalpur, Pakistan
}

${ }^{7}$ Directorate of Agriculture Extension and Adaptive Research, Government of Punjab, Lahore, Pakistan

*Corresponding author

e-mail:liaqatali@iub.edu.pk

(Received $11^{\text {th }}$ Apr 2019; accepted $11^{\text {th }}$ Jul 2019)

\begin{abstract}
Among abiotic stresses, high temperature is an obstructive factor in plant growth and physiological activities for sustainable agriculture, worldwide. Chitosan is a bio-based stimulant and may be helpful in reducing adversative effects of temperature stress. A field experiment was conducted to investigate the role of chitosan as high temperature stress regulator in two eggplant genotypes (Black boy and Sandhya) under arid environment. Temperature stress was maintained by delayed planting of eggplant as compared to its optimum planting time. Results showed that foliar application of chitosan has significantly improved the eggplant growth and yield characteristics. The effect of chitosan was more prominent on the genotype Black boy over Sandhya and recovery of plants improved with the increase in its application rate. The maximum yield was obtained in Black boy that was $42 \%$ higher to control and $14 \%$ to Sandhya at chitosan application of $175 \mathrm{mg} \mathrm{L} \mathrm{L}^{-1}$. Application of chitosan also improved the proline content, glycinebetain, total soluble solids and total phenolics accumulation. The late season high temperature stress significantly reduced the linear electron flow and non-photochemical quenching but the application of chitosan significantly improved both these characters. The positive effect of chitosan on plant physiochemical traits was more promising on genotype Black boy over Sandhya. These findings showed that the chitosan can be used as an ecofriendly compound to enhance plants activities under stress conditions.
\end{abstract}

Keywords: climate change, chitosan, high temperature, photosynthesis, fruit generative 


\section{Introduction}

Climate change is expected to continue increasing and poses regionally differing threats to agriculture in this World. South Asia is snowballing in the last few decades and the situation is further becoming severe in global warming scenario (IPCC, 2014). The high concentration of population in this region generally reliance on natural resources and agriculture along the coastal areas to derive their economy and development for their livelihood. Currently, declining soil productivity and extreme weather conditions; rising temperature, salinity, drought as well as deforestation have had sever affects posing a threat to throw the countries back into the poverty trap. The efforts regarding adjustment and mitigation of the source climate change such as greenhouse gas emissions by burning of fossils fuels, as well as deforestation and urbanization, are needed to combat this issue (Churkina, 2016; Mgbemene et al., 2016; Myers et al., 2017). Agriculture and food security is a fundamental human activity at risk by this global warming. The rising temperature is the key factor controlling the cropping patterns and water availability in coming decades (Rasul, 2016; Teixeira et al., 2013).

Temperature is the primary determinant of crop production, particularly in arid areas (Ihsan et al., 2016). Temperature controls the rate of plant metabolic processes that is ultimate source of biomass, phytonutrients, fruit development and yield of plant. The photosynthetic rates peak at about $30{ }^{\circ} \mathrm{C}$ and decreases thereafter $17 \%$ for each degree Centigrade in average (Ali et al., 2011; Lobell and Asner, 2003). High temperature affects plant physiology at both cellular and whole plant through stomatal conductance and osmotic pressure. High temperature stress reduces plant growth and development through excessive evapotranspiration effects, may lead to nutritional imbalance such as sulphur, specific ion effects as well as low turgor potential of plant (Ihsan et al., 2016). The adding effect of each of these factors can affect plant processes like lipid peroxidation, photosynthesis, energy and protein formation.

The high temperature in addition with drought spells encourage more 'harmful impact on growth parameters such as plant height, the number of leaves per plant, shoot dry weight, shoot length, root length, flower induction, and ultimately the yield attributes (Ainsworth and Ort, 2010; Jiao et al., 2012; Shehata et al., 2012).

Eggplant (Solanum melongena L.) is a well-known vegetable, widely cultivated in central, south Asia and some African countries (Hazra et al., 2003; Ranil et al., 2017). The ideal temperature for plant growth and fruit development lies between $22^{\circ} \mathrm{C}$ and $30{ }^{\circ} \mathrm{C}$. With an unnatural weather change, temperature in south Asia is often over $35^{\circ} \mathrm{C}$, which is not suitable for growth, flower bud formation, and may cause pollen infertility (Pandit et al., 2010). Such damage is estimated to the reduced harvest and subsequently low yield. Currently, attempts to measure the potential benefits of climate mitigation actions on the agricultural sector, which have been put forward, such as heat-tolerant varieties, improving irrigation systems and certain cultivation measures. However, the use of bio-stimulants, such as chitosan or chitin could be one of the approaches to cope with the negative impact of abiotic stress such as high temperature and heat stress.

Chitosan (CTS) are polysaccharides, a derivative of chitin, obtained from the waste products of sea food is one of the most preferred biopolymers, harmless to plants, animals and, since the last decade, chitosan uses are increasing due to its non-toxicity, biodegradability, biocompatibility, and stimulant to cell activation and plant growth (Elieh-Ali-Komi and Hamblin, 2016). Previous studies reported chitosan use in 
agriculture to manage abiotic stresses and to improve crop production and quality (Katiyar et al., 2015; Sharif et al., 2018).

Chitosan prevents adverse effects of the abiotic stresses in plants through regulating different mechanisms. Application of chitosan boosted photosynthesis that elicited the scavenging of reactive oxygen species under stress conditions. Chitosan involved in protecting plants from high temperature stress and photo-damage through production of heat shock proteins (Chandra et al., 2015; Landi et al., 2017). The first protein complex (PSII) is more sensitive than PSI (Allakhverdiev et al., 2008; De Ronde et al., 2004; Sonoike, 2011). High temperature stress above $40{ }^{\circ} \mathrm{C}$ inhibit PSII activity through denaturation of this protein complex and inhibiting of enzymes activity (Kehoe, 2010; Walters, 2005). The other mechanism damaged through high temperature stress in plants is the thylakoid proton conductance (Baker et al., 2007; Rochaix, 2011). In some plants these mechanisms are more chilling sensitive than high temperature stress (Sonoike, 2011).

The positive role of chitosan in various stresses management is well documented in different crops. Its role in high temperature stress management in eggplant (Solanum melongena L.) has been never studied and reported. Considering chitosan positive response in different stresses management in agriculture crops, the present study is designed to evaluate its role in PSII regulation and osmoprotectant (proline, soluble carbohydrates, and glycinebetaine) performance under high temperature stress in eggplant (S. melongena L.) genotypes. Moreover, the effect of chitosan will be studied on crop agronomic and fruit generative characters.

\section{Material and methods}

\section{Experimental site and soil preparation}

The field experiment was conducted in the research area of 'The Islamia University of Bahawalpur $\left(29.35^{\circ} \mathrm{N}, 71.69^{\circ} \mathrm{E}\right)$., near cholistan desert, Pakistan (Fig. 1). The climate of the experimental location is arid with sever hot summer and cool dry winter (Table 1). The experimental plots were prepared by deep ploughing, after the harvest of Maize crop. The eggplant (Solanum melongena) seedlings were obtained from a vegetable crops nursery near Lahore, Punjab and transplanted on $27^{\text {th }}$ March 2017. In this experiment, a randomized complete block design was used with three replications. The experimental bed size was $1.5 \mathrm{~m} \times 0.6 \mathrm{~m}$, with plant density 7.12 plants $\mathrm{m}^{-2}$. The plantation was made on the both sides of the beds. Plant to plant distance was maintained at $45 \mathrm{~cm}$ while row to row distance was maintained at $30 \mathrm{~cm}$ apart. The nonexperimental area of approximately 1 meter $(0.92 \mathrm{~m})$ left fallowed between two blocks.

\section{Treatments application}

Two eggplant genotypes (Black boy and Sandhya) were tested against chitosan application for heat stress mitigation on somatic and generative characters. Chitosan was applied at five different levels. Chitosan levels were comprised of T0: $0 \mathrm{mg} \mathrm{L}^{-1}, \mathrm{~T} 1$ : $125 \mathrm{mg} \mathrm{L}^{-1}$, T2: $150 \mathrm{mg} \mathrm{L}^{-1}$, T3: $175 \mathrm{mg} \mathrm{L}^{-1}$ and T4: $200 \mathrm{mg} \mathrm{L}^{-1}$ respectively (Table 2). Chitosan application was based into different phases, depending on plant vegetative and developmental stage. The heat stress was maintained by late planting in March that initiated flowering in the hot months of June and July. 


$$
-11276 \text { - }
$$

Table 1. Monthly temperature, relative humidity, wind speed and rainfall during the crop growing season

\begin{tabular}{c|c|c|c|c|c}
\hline \multirow{2}{*}{ Month } & \multicolumn{2}{|c|}{ Temperature $^{\circ} \mathbf{C}$} & $\begin{array}{c}\text { Relative humidity } \\
(\%)\end{array}$ & Wind speed (KPH) & Rainfall (mm) \\
\cline { 2 - 6 } & Maximum & Minimum & 45 & 10 & - \\
\hline March & 40 & 17.4 & 31 & 13 & - \\
April & 44 & 23.6 & 27 & 16 & 12 \\
May & 49 & 26.29 & 24 & 14 & 200 \\
June & 49 & 30 & 48 & 13 & 118 \\
July & 45 & 28.29 & 47 & 12 & 145 \\
August & 44 & 27.6 & 46 & 12 & - \\
September & 44 & 23.6 & 38 & 8 & - \\
October & 42 & 16.38 & 38 & \\
\hline
\end{tabular}

Observation in each column are based on monthly data means

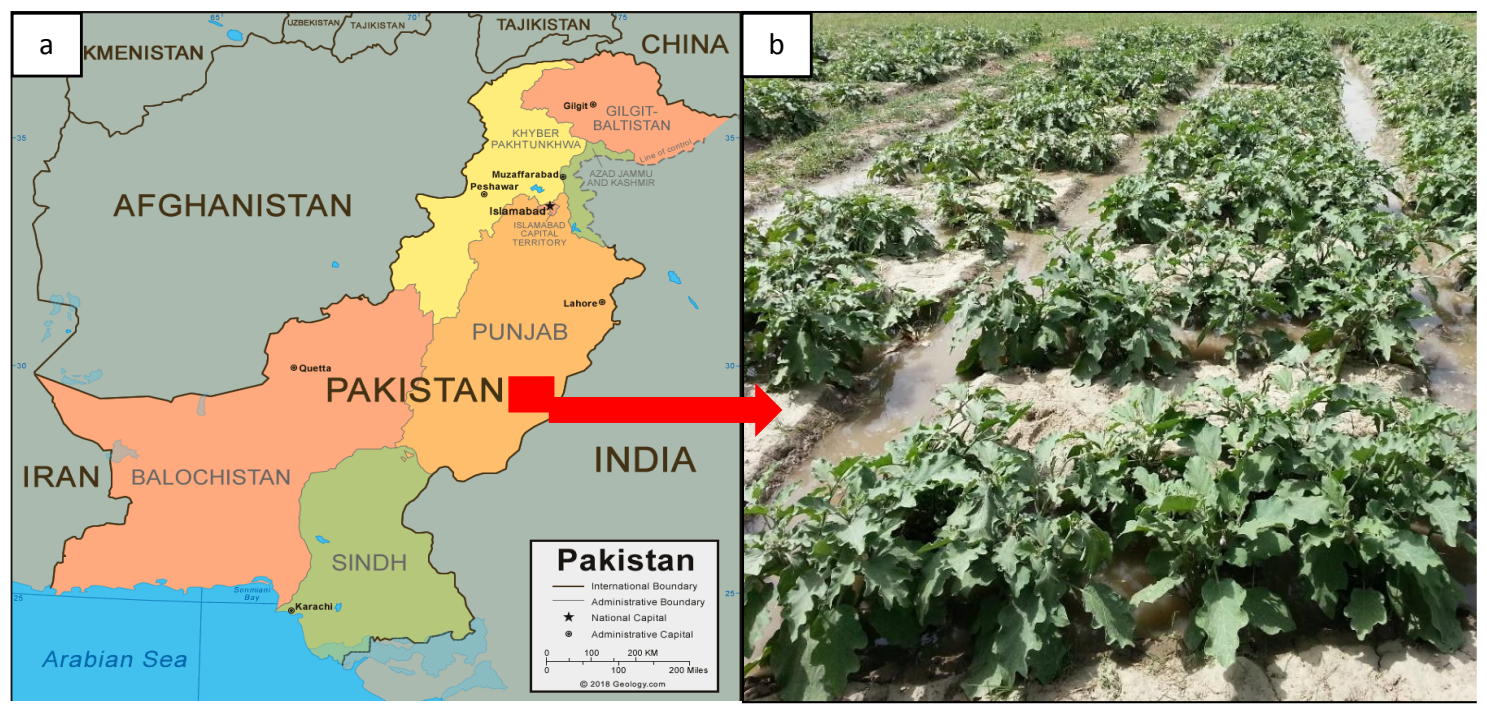

Figure 1. Location of the experimental region ( $a=a$ map of the experimental region, $b=a$ photo of the experimental block)

Table 2. Details of different chitosan treatments used in experiment of eggplant (Solanum melongena L.) genotypes under heat and high irradiance

\begin{tabular}{c|c|c}
\hline Parameters & & Uses \\
\hline \multirow{4}{*}{ Treatment } & T0 & Control $\left(0 \mathrm{mg} \mathrm{L}^{-1}\right)$ \\
& T1 & $125 \mathrm{mg} \mathrm{L}^{-1}$ \\
& T2 & $150 \mathrm{mg} \mathrm{L}^{-1}$ \\
& T3 & $175 \mathrm{mg} \mathrm{L}^{-1}$ \\
& T4 & $200 \mathrm{mg} \mathrm{L}^{-1}$ \\
\hline \multirow{2}{*}{ Variety } & V1 & Black boy \\
& V2 & Sandhya \\
\hline
\end{tabular}

The chitosan was added as fumigant. The growing season was grouped into five phases, and the application of chitosan was based on the requirement and growth of the crop stage 


\section{Data collection/sampling}

The Data recording was made randomly, 5 plants from each bed, 15 plants from each block and 30 plants from each treatment. The measurements were made for number of leaves, shoot fresh weight, root fresh weight, no of flowers per plant, no of fruits per plant, shoot/root ratio and pant biomass. Chemical analysis of leaf for antioxidant enzymes, i.e., proline, glycinebetaine and total phenolics were also performed at full maturity stage. Measurements were also made for net photosynthesis, linear electron flow and Non-photochemical quenching when plants produced first fruit. Five plants for each treatment were up-rooted and washed to remove debris and soil particles. Shoot length; from hypocotyl to the tip of the shoot was measure in centimeters. Similarly, the root length was calculated from base of hypocotyl to the tip of root. Root/shoot fresh and dry weight and fruit weight were measured in grams with the help of electrical balance. Number of leaves, shoots, flowers and fruits were counted manually at maturity stage. Flower drop were measured by subtracting total number of fruits from total number of flowers.

For the extraction of total soluble sugars, lyophilized leaf samples, $0.05 \mathrm{~g}$ was extracted in $5 \mathrm{~mL}$ solvent of $80 \%$ ethanol for $24 \mathrm{~h}$ according to prescribed method of Schortemeyer et al. (1997). Absorbance was measured at $623 \mathrm{~nm}$ using a Cary 50 Bio spectrophotometer (Varian, Australia). The total phenolic contents were measured according to the Folin-Ciocalteau method modified to Dewanto et al. (2002). Absorbance was measured at $765 \mathrm{~nm}$ using a Cary 50 Bio spectrophotometer (Varian, Australia). Quantification was carried out by comparison against the external standard gallic acid, 3,4,5-trihydroxybenzoic acid (Sigma-Aldrich, Germany). The amount of glycinebetaine was estimated according to the method of Grieve and Grattan (1983). The absorbance for glycinebetaine (GB) was measured at $365 \mathrm{~nm}$ using a Varian Cary 50 spectrophotometer (Agilent Technologies Inc., USA). Proline was extracted according to the method of Bates et al. (1973), with some modifications. The absorbance was noted at $520 \mathrm{~nm}$ using a double beam spectrophotometer (Hitachi-120, Japan). Proline concentration was determined from a standard curve and calculated on dry weight basis.

To determine whether the tested eggplant ( $S$. melongena $\mathrm{L})$ plants are involved in photoinhibition and repair processes, PSII activity was measured. The dissipation of excess light energy as heat was monitored by measuring the development of NPQt. Photosynthesis and energy dissipation was measured on field-grown plants using a PhotosynQ, portable photosynthesis system (Kuhlgert et al., 2016).

\section{Statistics}

Five replicate samples were used for each factor. Data for the level of chitosan was evaluated by analysis of variance (ANOVA) followed by Tukey's studentized range test (HSD) (P < 0.05) using SPSS version 18.0 (SPSS Inc., Chicago, II., USA). The level of chitosan was taken as independent factor while physiological and biochemical indices as dependent factor. Descriptive analysis (SPSS Inc., Chicago, II., USA were made to reveal the differences between data. Differences were considered to be significant at $\mathrm{p}<0.05$. 


\section{Results}

Foliar application of chitosan significantly improved the eggplant growth and yield characteristics except for number of leaves plant ${ }^{-1}$ and number of flowers per plant ${ }^{-1}$; however, the improvement was dependent on the chitosan dose and the eggplant genotype. Generally, the increase in chitosan level increased the growth and yield of both genotypes (Tables 3 and 4). However, the varietal response was variable for different growth parameters to different applied levels of chitosan. The effect of chitosan was significant for, plant height, number of shoots plant $^{-1}$, root length, root fresh weight and root dry weight for Black boy and plant height, number of shoots plant $^{-1}$, root length and root dry weight (Table 5). Similarly, the effect of chitosan was significant for number of fruits plant ${ }^{-1}$, weight of each fruit and yield plant ${ }^{-1}$ for Black boy. While the number of fruits per plant ${ }^{-1}$, flower drop plant ${ }^{-1}$, weight of each fruit, yield plant $^{-1}$ and flower drop percentage for Sandhya genotype (Table 6).

Table 3. ANOVA comparison for different levels of chitosan on the morphological traits of eggplant (Solanum melongena L.) genotypes under heat and high irradiance

\begin{tabular}{|c|c|c|c|c|c|c|c|c|c|}
\hline \multirow{2}{*}{ Source of variation } & & \multicolumn{4}{|c|}{ Var-1 } & \multicolumn{4}{|c|}{ Var-2 } \\
\hline & & Replication & Treatment & Error & Total & Replication & Treatment & Error & Total \\
\hline \multirow{4}{*}{ No of leaves plant ${ }^{-1}$} & Degree of freedom & 7 & 4 & 28 & 39 & 7 & 4 & 28 & 39 \\
\hline & Mean squares & & 100.25 & & & & 116.6 & & \\
\hline & F-value & & 2.348 & & & & 1.822 & & \\
\hline & P-value & & $0.073^{\mathrm{NS}}$ & & & & $0.147^{\mathrm{NS}}$ & & \\
\hline \multirow{4}{*}{ Plant height } & Degree of freedom & 7 & 4 & 28 & 39 & 7 & 4 & 28 & 39 \\
\hline & Mean squares & & 61.562 & & & & 155.855 & & \\
\hline & F-value & & 5.989 & & & & 9.343 & & \\
\hline & P-value & & $0.001 * *$ & & & & $0.000 * * *$ & & \\
\hline \multirow{4}{*}{ No of shoots plant ${ }^{-1}$} & Degree of freedom & 7 & 4 & 28 & 39 & 7 & 4 & 28 & 39 \\
\hline & Mean squares & & 2.088 & & & & 4.588 & & \\
\hline & F-value & & 2.894 & & & & 4.621 & & \\
\hline & P-value & & $0.036^{*}$ & & & & $0.004 * *$ & & \\
\hline \multirow{4}{*}{$\begin{array}{l}\text { Root length } \\
\quad(\mathrm{cm})\end{array}$} & Degree of freedom & 7 & 4 & 28 & 39 & 7 & 4 & 28 & 39 \\
\hline & Mean squares & & 48.375 & & & & 44.412 & & \\
\hline & F-value & & 22.727 & & & & 18.899 & & \\
\hline & P-value & & $0.000 * * *$ & & & & $0.000^{* * * *}$ & & \\
\hline \multirow{4}{*}{ Fresh weight root } & Degree of freedom & 7 & 4 & 28 & 39 & 7 & 4 & 28 & 39 \\
\hline & Mean squares & & 93.85 & & & & 62.9 & & \\
\hline & F-value & & 3.207 & & & & 2.164 & & \\
\hline & P-value & & $0.024 *$ & & & & $0.094^{\mathrm{NS}}$ & & \\
\hline \multirow{4}{*}{ Dry weight root } & Degree of freedom & 7 & 4 & 28 & 39 & 7 & 4 & 28 & 39 \\
\hline & Mean squares & & 15.538 & & & & 40.962 & & \\
\hline & F-value & & 5.149 & & & & 19.44 & & \\
\hline & P-value & & $0.002 * *$ & & & & $0.000 * * *$ & & \\
\hline
\end{tabular}

Probability level at $5 \%, \mathrm{P} \leq 0.001 * * *, \mathrm{NS}=$ Non-significant, Var-1 = variety 1 , Var-2 = variety 2

The response of genotypes for above mentioned traits was maximum at $150 \mathrm{mg} \mathrm{L}^{-1}$ to $175 \mathrm{mg} \mathrm{L}^{-1}$ for most of the traits except for fresh weight of root $(125 \mathrm{~g})$ and flower drop \% (62\%) in Sandhya that was the highest at low concentration $\left(125 \mathrm{mg} \mathrm{L}^{-1}\right)$ of chitosan. During the developmental stages, maximum plant height was recorded with chitosan dose of $175 \mathrm{mg} \mathrm{L}^{-1}$ in both of the genotypes; $73.99 \mathrm{~cm}$ in Black boy and 64.70 
$\mathrm{cm}$ in Sandhya (Table 5). The maximum number of shoots plant $^{-1}$ was recorded in Sandhya that was $21 \%$ higher to control and $3 \%$ to Black boy. The root length was significantly varied under chitosan treatments compared to control $(\mathrm{P}<0.05)$. The maximum root length was noticed when treated with chitosan at $175 \mathrm{mg} \mathrm{L}^{-1}$ in both genotypes of eggplant. The root length was ranged between 17-23 cm in genotype Black boy and 16-22 $\mathrm{cm}$ in genotype Sandhya. The mean shoot dry weight was increased up to $22 \%$ in Sandhya and $15 \%$ in Black boy over control with the increase in chitosan dose from $150 \mathrm{mg} \mathrm{L}^{-1}$ to $175 \mathrm{mg} \mathrm{L}^{-1}$ respectively.

Table 4. ANOVA comparison for different levels of chitosan on the yield component traits of eggplant (Solanum melongena L.) genotypes under heat and high irradiance

\begin{tabular}{|c|c|c|c|c|c|c|c|c|c|}
\hline \multirow{2}{*}{ Source of variation } & & \multicolumn{4}{|c|}{ Var-1 } & \multicolumn{4}{|c|}{ Var-2 } \\
\hline & & Replication & Treatment & Error & Total & Replication & Treatment & Error & Total \\
\hline \multirow{4}{*}{ No of flowers plant ${ }^{-1}$} & Degree of freedom & \begin{tabular}{|l|}
7 \\
\end{tabular} & 4 & 28 & 39 & 7 & 4 & 28 & 39 \\
\hline & Mean squares & & 57.400 & & & & 21.85 & & \\
\hline & F-value & & 2.415 & & & & 0.691 & & \\
\hline & P-value & & $0.067^{\mathrm{NS}}$ & & & & $0.603^{\mathrm{NS}}$ & & \\
\hline \multirow{4}{*}{ No of fruit plant ${ }^{-1}$} & Degree of freedom & 7 & 4 & 28 & 39 & 7 & 4 & 28 & 39 \\
\hline & Mean squares & & 61.562 & & & & 136.462 & & \\
\hline & F-value & & 5.989 & & & & 9.608 & & \\
\hline & P-value & & $0.001 * *$ & & & & $0.000^{* * * *}$ & & \\
\hline \multirow{4}{*}{ Flower drop plant ${ }^{-1}$} & Degree of freedom & 7 & 4 & 28 & 39 & 7 & 4 & 28 & 39 \\
\hline & Mean squares & & 5.588 & & & & 225.288 & & \\
\hline & F-value & & 0.285 & & & & 6.709 & & \\
\hline & P-value & & $0.886^{\mathrm{NS}}$ & & & & $0.000 * * *$ & & \\
\hline \multirow{4}{*}{ Weight of each fruit } & Degree of freedom & 7 & 4 & 28 & 39 & 7 & 4 & 28 & 39 \\
\hline & Mean squares & & 307.588 & & & & 244.15 & & \\
\hline & F-value & & 5.086 & & & & 5.346 & & \\
\hline & P-value & & $0.002 * *$ & & & & $0.002 * *$ & & \\
\hline \multirow{4}{*}{ Yield plant $^{-1}$} & Degree of freedom & 7 & 4 & 28 & 39 & 7 & 4 & 28 & 39 \\
\hline & Mean squares & & 0.844 & & & & 1.757 & & \\
\hline & F-value & & 19.362 & & & & 45.625 & & \\
\hline & P-value & & $0.000 * * *$ & & & & $0.000 * * *$ & & \\
\hline \multirow{4}{*}{ Flower drop (\%) } & Degree of freedom & 7 & 4 & 28 & 39 & 7 & 4 & 28 & 39 \\
\hline & Mean squares & & 42.846 & & & & 429.811 & & \\
\hline & F-value & & 2.122 & & & & 9.796 & & \\
\hline & P-value & & $0.099^{\mathrm{NS}}$ & & & & $0.000 * * *$ & & \\
\hline
\end{tabular}

Probability level at $5 \%, \mathrm{P} \leq 0.001 * * *, \mathrm{NS}=$ Non-significant, Var-1 = variety 1 , Var-2 = variety 2

Both genotypes attained almost similar amount of root fresh weight at medium dose of chitosan and that was only $7 \%$ higher to control. The effect of chitosan was nonsignificant for genotype Sandhya root fresh weight. The maximum root dry matter (26.87 g) was recorded in Black boy that was slightly higher than Sandhya at chitosan dose of $175 \mathrm{mg} \mathrm{L}^{-1}$ while Sandhya attained almost similar amount of root dry weight at chitosan dose of $150 \mathrm{mg} \mathrm{L}^{-1}$ (Table 5).

Chitosan have non-significant influence on number of flowers induced in both genotypes. The values were ranged between 61.38 to 67.88 in Black boy and 61.75 to 65.75 in Sandhya genotype (Table 4). At low dose of chitosan, the flower drop was maximum for Sandhya. Genotypes varied significantly in terms of fruit number. A 
higher number of fruits were noted in genotype Black boy (36.75) as compared to Sandhya. Exogenous application of chitosan has also a significant influence on yield of eggplant genotypes. The maximum yield was attained at $175 \mathrm{mg} \mathrm{L}^{-1}$ in Black boy that was $42 \%$ higher to control and $14 \%$ to Sandhya at the same level of chitosan. This higher yield was due to a low flower drop and higher fruit setting at $175-200 \mathrm{mg} \mathrm{L}^{-1}$ chitosan application.

Table 5. Effect of chitosan on the morphological traits of eggplant (Solanum melongena L.) genotypes under heat and high irradiance

\begin{tabular}{c|c|c|c|c|c}
\hline Treatment & $\begin{array}{c}\text { Plant height } \\
(\mathbf{c m})\end{array}$ & $\begin{array}{c}\text { No of shoots } \\
\text { plant }^{-1}\end{array}$ & $\begin{array}{c}\text { Root length } \\
(\mathbf{c m})\end{array}$ & $\begin{array}{c}\text { Fresh weight root } \\
(\mathbf{g})\end{array}$ & $\begin{array}{c}\text { Dry weight root } \\
(\mathbf{g})\end{array}$ \\
\hline $\mathbf{T}_{\mathbf{0}} \mathbf{V}_{\mathbf{1}}$ & $62.38 \pm 1.53 \mathrm{~b}$ & $7.63 \pm 0.32 \mathrm{~b}$ & $18.63 \pm 0.59 \mathrm{c}$ & $116.13 \pm 3.06 \mathrm{~b}$ & $23.38 \pm 0.75 \mathrm{~b}$ \\
$\mathbf{T}_{\mathbf{1}} \mathbf{V}_{\mathbf{1}}$ & $69.15 \pm 1.50 \mathrm{a}$ & $8.25 \pm 0.36 \mathrm{ab}$ & $17.38 \pm 0.26 \mathrm{c}$ & $120.00 \pm 2.28 \mathrm{ab}$ & $24.75 \pm 0.55 \mathrm{ab}$ \\
$\mathbf{T}_{2} \mathbf{V} \mathbf{1}$ & $71.85 \pm 1.27 \mathrm{a}$ & $9.00 \pm 0.26 \mathrm{a}$ & $20.88 \pm 0.69 \mathrm{~b}$ & $125.00 \pm 1.52 \mathrm{a}$ & $24.63 \pm 0.59 \mathrm{ab}$ \\
$\mathbf{T}_{\mathbf{3}} \mathbf{V}_{\mathbf{1}}$ & $73.99 \pm 1.63 \mathrm{a}$ & $8.63 \pm 0.26 \mathrm{ab}$ & $23.00 \pm 0.56 \mathrm{a}$ & $121.25 \pm 0.97 \mathrm{ab}$ & $26.87 \pm 0.54 \mathrm{a}$ \\
$\mathbf{T}_{\mathbf{4}} \mathbf{V}_{\mathbf{1}}$ & $70.63 \pm 1.82 \mathrm{a}$ & $8.50 \pm 0.26 \mathrm{ab}$ & $22.63 \pm 0.32 \mathrm{ab}$ & $123.50 \pm 0.65 \mathrm{ab}$ & $26.25 \pm 0.59 \mathrm{a}$ \\
\hline $\mathbf{T}_{\mathbf{0}} \mathbf{V}_{\mathbf{2}}$ & $54.26 \pm 1.49 \mathrm{c}$ & $7.63 \pm 0.37 \mathrm{~b}$ & $16.87 \pm 0.54 \mathrm{c}$ & $118.00 \pm 2.22 \mathrm{a}$ & $20.75 \pm 0.45 \mathrm{~b}$ \\
$\mathbf{T}_{\mathbf{1}} \mathbf{V}_{\mathbf{2}}$ & $63.75 \pm 0.92 \mathrm{a}$ & $8.25 \pm 0.36 \mathrm{ab}$ & $19.00 \pm 0.56 \mathrm{bc}$ & $125.00 \pm 2.97 \mathrm{a}$ & $25.00 \pm 0.65 \mathrm{a}$ \\
$\mathbf{T}_{\mathbf{2}} \mathbf{V}_{\mathbf{2}}$ & $57.25 \pm 1.60 \mathrm{bc}$ & $7.63 \pm 0.37 \mathrm{~b}$ & $19.25 \pm 59 \mathrm{~b}$ & $120.00 \pm 1.16 \mathrm{a}$ & $26.63 \pm 0.41 \mathrm{a}$ \\
$\mathbf{T}_{\mathbf{3}} \mathbf{V}_{\mathbf{2}}$ & $64.70 \pm 1.35 \mathrm{a}$ & $9.25 \pm 0.36 \mathrm{a}$ & $22.63 \pm 0.41 \mathrm{a}$ & $123.25 \pm 1.11 \mathrm{a}$ & $24.87 \pm 0.54 \mathrm{a}$ \\
$\mathbf{T}_{\mathbf{4}} \mathbf{V}_{\mathbf{2}}$ & $61.26 \pm 1.71 \mathrm{ab}$ & $9.00 \pm 0.26 \mathrm{ab}$ & $22.00 \pm 0.56 \mathrm{a}$ & $123.00 \pm 1.33 \mathrm{a}$ & $25.75 \pm 0.45 \mathrm{a}$ \\
\hline
\end{tabular}

Mean values $( \pm$ SD) for all determinants are based on $n=8$. Different letters within column indicate significant differences between levels of chitosan, T0, T1, T2, T3 and T4 (p < 0.05). Treatment (T) 0: control; T1: $125 \mathrm{mg} \mathrm{L}^{-1}$; T2: $150 \mathrm{mg} \mathrm{L}^{-1}$; T3: $175 \mathrm{mg} \mathrm{L}^{-1}$; $\mathrm{T} 4: 200 \mathrm{mg} \mathrm{L}^{-1}$

Table 6. Effect of chitosan on the yield component traits of the eggplant (Solanum melongena L.) genotypes under heat and high irradiance

\begin{tabular}{c|c|c|c|c|c}
\hline Treatment & $\begin{array}{c}\text { No of fruit plant } \\
\mathbf{- 1}\end{array}$ & $\begin{array}{c}\text { Flower drop } \\
\text { plant }^{-1}\end{array}$ & $\begin{array}{c}\text { Weight of each } \\
\text { fruit }(\mathbf{g})\end{array}$ & $\begin{array}{c}\text { Yield plant } \\
\text { (kg) }\end{array}$ & $\begin{array}{c}\text { Flower drop } \\
(\boldsymbol{\%})\end{array}$ \\
\hline $\mathbf{T}_{\mathbf{0}} \mathbf{V}_{\mathbf{1}}$ & $29.75 \pm 0.75 \mathrm{~b}$ & $31.63 \pm 1.59 \mathrm{a}$ & $66.88 \pm 2.43 \mathrm{~b}$ & $1.99 \pm 0.06 \mathrm{~b}$ & $51.36 \mathrm{a}$ \\
$\mathbf{T}_{\mathbf{1}} \mathbf{V}_{\mathbf{1}}$ & $35.63 \pm 1.14 \mathrm{a}$ & $31.00 \pm 1.74 \mathrm{a}$ & $74.50 \pm 2.87 \mathrm{ab}$ & $2.04 \pm 0.06 \mathrm{~b}$ & $46.38 \mathrm{a}$ \\
$\mathbf{T} \mathbf{2} \mathbf{V}$ & $34.50 \pm 1.03 \mathrm{a}$ & $32.75 \pm 1.58 \mathrm{a}$ & $83.38 \pm 3.12 \mathrm{a}$ & $2.04 \pm 0.06 \mathrm{~b}$ & $48.58 \mathrm{a}$ \\
$\mathbf{T}_{\mathbf{3}} \mathbf{V}_{\mathbf{1}}$ & $36.75 \pm 1.29 \mathrm{a}$ & $30.63 \pm 1.19 \mathrm{a}$ & $79.50 \pm 2.66 \mathrm{a}$ & $2.77 \pm 0.07 \mathrm{a}$ & $45.44 \mathrm{a}$ \\
$\mathbf{T}_{\mathbf{4}} \mathbf{V}_{\mathbf{1}}$ & $35.87 \pm 1.34 \mathrm{a}$ & $32.00 \pm 1.65 \mathrm{a}$ & $77.50 \pm 2.59 \mathrm{ab}$ & $2.19 \pm 0.09 \mathrm{~b}$ & $47.06 \mathrm{a}$ \\
\hline $\mathbf{T}_{\mathbf{0}} \mathbf{V}_{\mathbf{2}}$ & $24.88 \pm 1.13 \mathrm{~b}$ & $29.50 \pm 2.65 \mathrm{~b}$ & $67.87 \pm 2.74 \mathrm{c}$ & $1.82 \pm 0.05 \mathrm{c}$ & $46.38 \mathrm{~b}$ \\
$\mathbf{T}_{\mathbf{1}} \mathbf{V}_{\mathbf{2}}$ & $34.13 \pm 0.51 \mathrm{a}$ & $40.87 \pm 1.44 \mathrm{a}$ & $78.50 \pm 2.52 \mathrm{a}$ & $1.82 \pm 0.04 \mathrm{c}$ & $62.02 \mathrm{a}$ \\
$\mathbf{T}_{\mathbf{2}} \mathbf{V}_{\mathbf{2}}$ & $34.50 \pm 2.11 \mathrm{a}$ & $31.00 \pm 1.10 \mathrm{~b}$ & $78.50 \pm 2.18 \mathrm{a}$ & $1.84 \pm 0.05 \mathrm{c}$ & $47.77 \mathrm{~b}$ \\
$\mathbf{T}_{\mathbf{3}} \mathbf{V}_{\mathbf{2}}$ & $34.25 \pm 1.37 \mathrm{a}$ & $27.25 \pm 2.77 \mathrm{~b}$ & $77.75 \pm 2.29 \mathrm{ab}$ & $2.47 \pm 0.08 \mathrm{~b}$ & $43.54 \mathrm{~b}$ \\
$\mathbf{T}_{\mathbf{4}} \mathbf{V}_{\mathbf{2}}$ & $33.37 \pm 0.98 \mathrm{a}$ & $29.87 \pm 1.71 \mathrm{~b}$ & $68.50 \pm 2.14 \mathrm{bc}$ & $2.83 \pm 0.09 \mathrm{a}$ & $46.47 \mathrm{~b}$ \\
\hline
\end{tabular}

Mean values $( \pm \mathrm{SD})$ for all determinants are based on $n=8$. Different letters within column indicate significant differences between levels of chitosan, T0, T1, T2, T3 and T4 ( $<<0.05)$. Treatment $(\mathrm{T}) 0$ : control; T1: $125 \mathrm{mg} \mathrm{L}^{-1}$; T2: $150 \mathrm{mg} \mathrm{L}^{-1}$; T3: $175 \mathrm{mg} \mathrm{L}^{-1}$; T4: $200 \mathrm{mg} \mathrm{L}^{-1}$

The effect of chitosan foliar application was also studied on plant physiological characters (Fig. 2). The proline content of both the genotypes increased significantly by increasing the chitosan application. There was synergistic stimulation with increased 
levels of chitosan. Proline concentration in eggplant leaves were ranged between 8.12 and $10.11 \mathrm{umol} / \mathrm{ml} \mathrm{DW}$ in Black boy and 8.30 to $9.48 \mathrm{umol} / \mathrm{ml} \mathrm{DW}$ in Sandhya genotype. However, the highest increase was observed at chitosan concentration of $175 \mathrm{mg} \mathrm{L}^{-1}$ in both genotypes. Similarly, the maximum concentration of glycinebetain $(8.53 \mathrm{ug} / \mathrm{ml} \mathrm{DW})$ was noticed in Black boy at the chitosan rate of $175 \mathrm{mg} \mathrm{L}^{-1}$ and that was $45 \%$ higher than control. The effect of chitosan application was also prominent on total soluble solids and total phenolics accumulation. As reported in other growth and yield traits, the highest dose of chitosan failed to produce the maximum accumulation of total soluble solids and total phenolics in both genotypes. The total phenolics in Black boy that was maximum (124 mg/g DW) at $175 \mathrm{mg} \mathrm{L}^{-1}$ of chitosan. Again, the satisfactory results were obtained at medium dose of chitosan that produced $31 \%$ higher total soluble solids and $18 \%$ higher total phenolics in Black boy and 33-16\% in Sandhya.
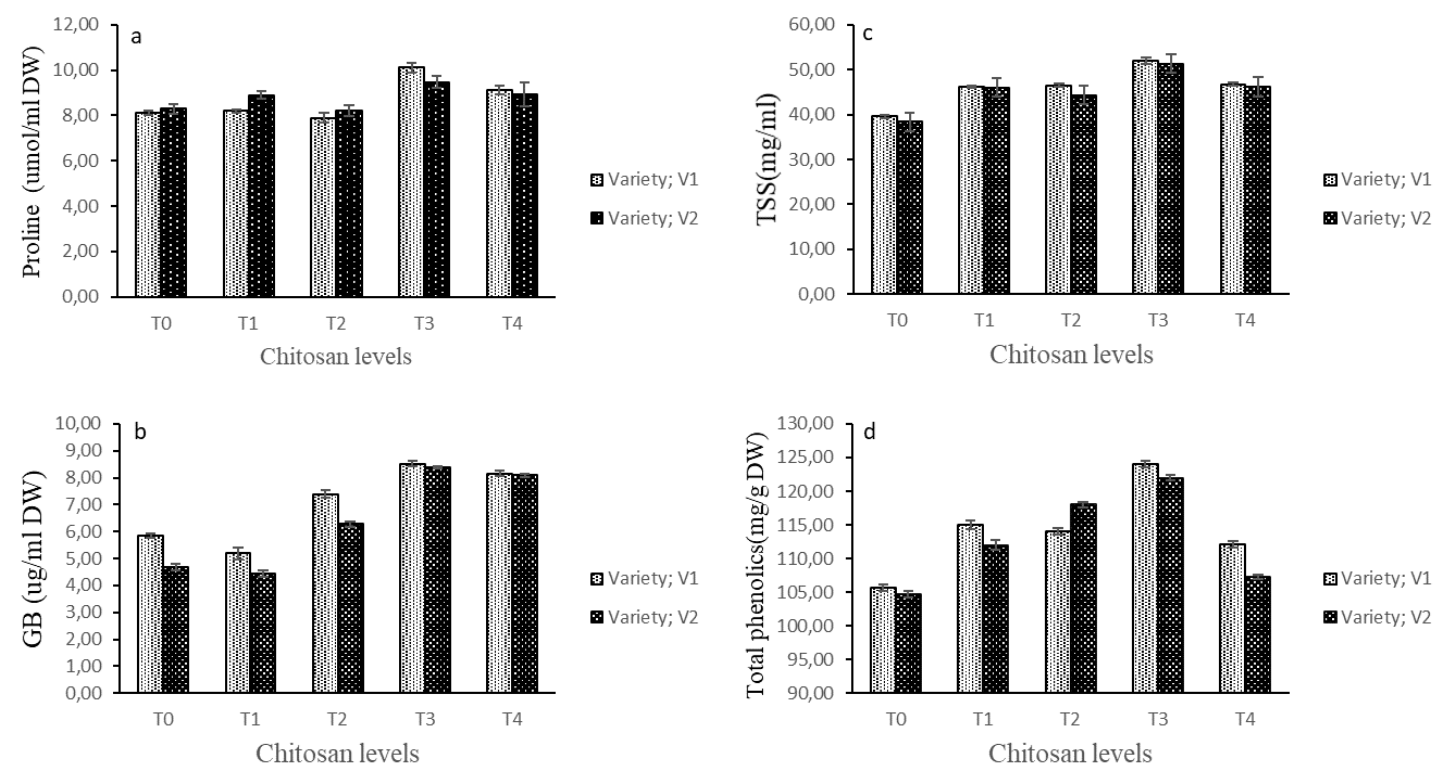

Figure 2. Mean values for Proline (umol/ml $D W \pm S D$ ), Glycinebetaine (ug//ml $D W \pm S D$ ),

Total soluble solids ( $\mathrm{mg} / \mathrm{ml} \mathrm{DW} \pm S D$ and Total phenolics $(\mathrm{mg} / \mathrm{g} D W \pm S D)$ of eggplant (Solanum melongena L.) genotypes subjected to different level of Chitosan (T0, T1, T2, T3, T4) under heat and high irradiance. Treatment (T) 0: control; T1: $125 \mathrm{mg} \mathrm{L}^{-1}$; T2: $150 \mathrm{mg} \mathrm{L}^{-1}$; T3: $175 \mathrm{mg} \mathrm{L}^{-1}$; T4: $200 \mathrm{mg} \mathrm{L}^{-1}$

The linear electron flow (LEF) was measured from the matured leaves of both varieties. Constant value of LEF was noticed in Black boy for all chitosan treatments except for control that produced the significant lower value for LEF. On contrary, the LEF gradually increased with the increase in chitosan dose in Sandhya genotype (Fig. 3). In addition, the non-photochemical quenching (NPQt) was monitored to evaluate the excess heat energy dissipation during high irradiance. The high temperature stress induced more severe NPQt in both genotypes' seedlings. The NPQt was directly influenced to the level of the high temperature and heat stress. Genotype Black boy produced higher NPQt (0.65) as compared the Sandhya that produced slightly lower value for NPQt (0.64). The quantum yield of photosystem II (PSII) has also measured to estimate the efficiency of photosystem II under high temperature stress. 
Exogenous chitosan application improved chlorophyll contents in both genotypes. The values were varied between 51.05 and 60.73 (SPAD) in Black boy and 54.75 and 60.83 (SPAD) in Sandhya during late planting high temperature stress. It was the lowest in control, gradually increased with the increase in chitosan dose level up to $175 \mathrm{mg} \mathrm{L}^{-1}$ and after that negatively responded to any increase in chitosan dose (Fig. 3).
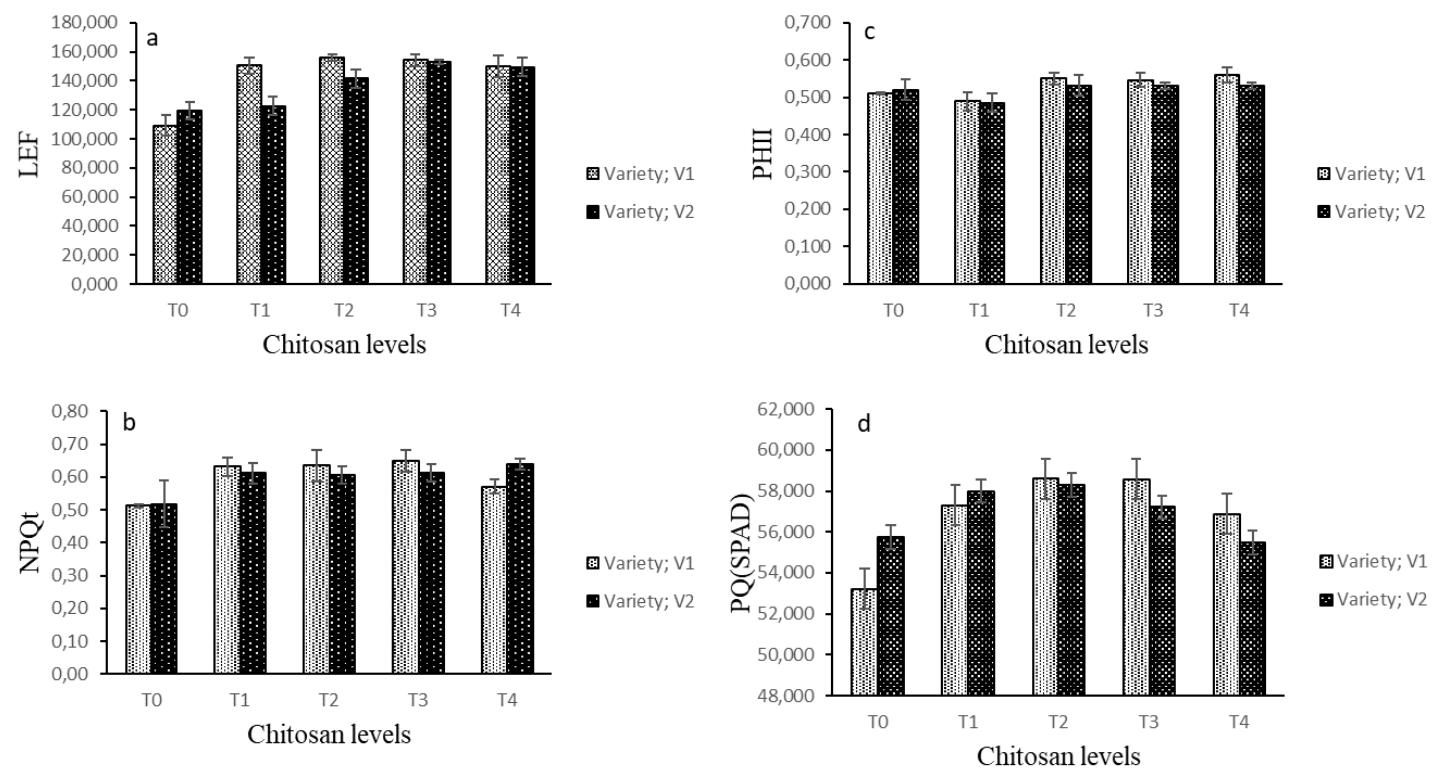

Figure 3. Mean values $( \pm S D)$ for Photosystem II, Linear electron flow, Non-photochemical quenching and $P Q$-spade of eggplant (Solanum melongena L.) genotypes subjected to different level of Chitosan (TO, T1, T2, T3, T4) under heat and high irradiance. Treatment (T) 0: control; T1: $125 \mathrm{mg} \mathrm{L}^{-1}$; T2: $150 \mathrm{mg} \mathrm{L}^{-1}$; T3: $175 \mathrm{mg} \mathrm{L}^{-1} ; \mathrm{T4}: 200 \mathrm{mg} \mathrm{L}^{-1}$

\section{Discussion}

Chitosan regulated plant growth, yield and physiological traits studied under high temperature stress. The mechanism of high temperature stress regulation is not still clearly established but however, chitosan application at different growth stages of the plants under stress stimulated the plant growth that has helped plant to withstand the adverse effects of the stress (Katiyar, 2015). The inactivation of enzymes involved in different processes of photosynthesis and the carbon flux are the major effects of high temperature stress.

Similarly, the photo inhibition was due to high light intensity, might be the other reason of plant growth inhibition (Guidi et al., 2019). Chitosan also has stimulated the activity of sucrose hydrolyzing enzymes in seedlings under stressful environment. The additive role of chitosan application has been found to synthesize plant hormones such as auxin and gibberellins by stimulating a signal related to biosynthesis and may help plant to maintain its growth and development under high temperature stress. Some studies have reported its involvement in protecting cell membrane from deterioration under abiotic stresses.

Chitosan application produced the highest shoot dry weight at a concentration of $0.01 \%$. A number of researchers reported similar results related to plant growth and yield improvement with the application of chitosan (Amiri et al., 2015; Safikhan et al., 2018). In this experiment, high temperature stress caused stunted eggplant growth, and 
this might be due to the low availability of nutrients and poor functioning of nutrient uptake mechanism due to impaired photosynthesis. Application of Chitosan improved photosynthesis through increasing leaf chlorophyll content that might has stabilized the cell membrane, detoxify the deleterious effects of antioxidant's, and helped in cell elongation and multiplication (Malerba and Cerana, 2016; Salachna and Zawadzińska, 2014). The improvement in these mechanisms ultimately resulted in significant yield improvement under high temperature stress.

It is concluded that foliar application of chitosan at vegetative stages enhance the plant growth and development (number of leaves, shoots length, pedicel length, plant height) which helped plants to secure fruiting and fruit yield in eggplant.

The physiological and biochemical responses of chitosan has been found to act as stimulator which ultimately encode a gene expression, and thereby plants treated with chitosan may be less prone to stress evoked unfavorable conditions such as high and low temperatures, drought as well as salinity (Zhao et al., 2008). Under high temperature stress, proline content, glycinebetain, total soluble sugars and total phenolics contents in leaves of eggplant genotypes decreased significantly. The application of chitosan improved the total phenolics level in both genotypes. The results are in agreement with previously investigations that reported positive role of chitosan in cell membrane permeability, concentration of soluble sugars and proline (Guan et al., 2009).

Accumulation of total free sugars and phenolic contents serves as adaptive mechanism in plants under high temperature stress. In the same manner osmolytes protect the cell membrane against adverse effects of heat stress. Accumulation of ions such as proline improves the membrane stability in plants and these ions uptake improve with the application of chitosan. Chitosan regulates stomatal closure, ion uptake and transpiration. Moreover, chitosan plays prolific role in many morphological and physiological functions of the plants (Safikhan, 2018).

Exogenous application of chitosan increased eggplant height through improvement in leaf chlorophyll content and number of leaves per plant. The growth stimulatory effects of chitosan on vegetative parts of plants especially number of leaves per plant, plant height and leaf chlorophyll content has previously reported in cucumber (Katiyar et al., 2015; Shehata et al., 2012) and safflower (Amiri et al., 2015). Chitosan foliar spray also helped to control insect pest attack, plant and fruit diseases. Chitosan is a natural, inert and cheap molecule that regulates different biological responses in plants depending upon its concentration, plant species and developmental stage.

We can measure the performance of a plant by its amount of chlorophyll content under stress condition. Chitosan application significantly increased chlorophyll content of both genotypes of eggplant. Foliar application of chitosan increased chlorophyll content of soybean (18\%) and peanut (23\%) (Dzung, 2005). Plants loss their chlorophyll content as a photo protection mechanism to reduce light absorbance at high temperature stress either by slow synthesis or fast breakdown of chlorophyll contents (Elsheery and Cao, 2008; Wise et al., 2004). Both eggplant genotypes showed positive response to applied chitosan spray through stabilizing the chlorophyll content and maintaining the photosynthetic rate (PSII). Involvement of chitosan has confirmed in modulating the activity of dimers and monomers during the protein synthesis (Sharif et al., 2018).

The NPQT of chlorophyll fluorescence is associated with a decrease in the rate of photosystem II. The NPQT measures the active percentage of PSII reaction center that 
is capable of photochemistry and changes in PSII (Guidi et al., 2019; Malerba and Cerana, 2016). Similar changes were also noticed in this study where NPQT was slightly increased or stabilized with increased level of chitosan however, this moderate increase was statistically not significant. Consequently, the decreased demand for product of electron transport that was used for assimilation resulted in heat dissipation of light energy.

Previously, it was reported that the abiotic stress may lead to a decrease in the photochemical efficiency and electron transport activity due to the changes in the structure of the photosynthetic apparatus (Guidi, 2019; Mittal, 2012). The results in this study suggest that chitosan can modulate moderately the flow of intercellular ion transport and enhances the activity of antioxidants enzymes which helps in preventing the membrane damage in the granal and stromal thylakoids under stress conditions (Malerba and Cerana, 2016; Salachna and Zawadzińska, 2014). The results in Figure $2 a, b$ regarding LEF and NPQT are in agreement with previous studies suggesting the photoinhibition through changes in protective high-energy-state by increase in NPQT (Guidi et al., 2019). Additionally, repair mechanisms such as excision repair, photoreactivation, quenching and free radical scavenging could be activated to prevent and slow down the damage caused by long exposure to high temperature stress by chitosan application (Choi et al., 2013; Zhang et al., 2008).

\section{Conclusion}

The exogenous application of chitosan has significant influence on the physiological and biochemical attributes of eggplant genotypes. Major changes were noticed in parameters affecting growth and development such as, flower induction, flower drop, fruits plant ${ }^{-1}$, weight of each fruit and yield plant ${ }^{-1}$. The effect was more prominent on Black boy over Sandhya cultivar. The thermostability of reaction center of PSII was also noticed, may possibly due to of less ROS accumulation, an aiding influence due to increased level of chitosan application. The chitosan application especially with concentration $175 \mathrm{mg} \mathrm{L}^{-1}$ improved the plant growth and development, increased the content of proline, glycinebetain, total soluble solids and total phenolics. The chitosan has moderated the influence of high temperature and heat stress by accelerating the antioxidant enzymes activities. The yield of the eggplant was positively changed to the level of chitosan application. The increased level of chitosan produced more yield under high temperature and heat stress. It can be concluded that chitosan may be used as an eco-friendly compound to protect and to enhance growth, development and other biochemical parameters under high temperature and heat stress.

\section{REFERENCES}

[1] Ainsworth, E. A., Ort, D. R. (2010): How do we improve crop production in a warming world? - Plant Physiology 154: 526-530.

[2] Ali, L., Svensson, B., Alsanius, B. W., Olsson, M. E. (2011): Late season harvest and storage of Rubus berries - major antioxidant and sugar levels. - Scientia Horticulturae 129: 376-381.

[3] Allakhverdiev, S., Kreslavskii, V., Klimov, V., Los, D., Carpentier, R., Mohanty, P. (2008): Heat stress: An overview of molecular responses in photosynthesis. Photosynthesis Research 98: 541. 
[4] Amiri, A., Sirousmehr, A., Esmaeilzadeh, B. S. (2015): Effect of foliar application of salicylic acid and chitosan on yield of safflower (Carthamus tinctorius L.). - Journal of Plant Research (Iranian Journal of Biology) 28(4): 712-725.

[5] Baker, N. R., Harbinson, J., Kramer, D. M. (2007): Determining the limitations and regulation of photosynthetic energy transduction in leaves. - Plant, Cell \& Environment 30: 1107-1125.

[6] Bates, L. S., Waldren, R. P., Teare, I. (1973): Rapid determination of free proline for water-stress studies. - Plant and Soil 39: 205-207.

[7] Chandra, S., Chakraborty, N., Dasgupta, A., Sarkar, J., Panda, K., Acharya, K. (2015): Chitosan nanoparticles: a positive modulator of innate immune responses in plants. Scientific Reports 5: 15195.

[8] Choi, Y.-S., Kim, Y.-M., Hwang, O.-J., Han, Y.-J., Kim, S. Y., Kim, J.-I. (2013): Overexpression of arabidopsisabf3 gene confers enhanced tolerance to drought and heat stress in creeping bentgrass. - Plant Biotechnology Reports 7: 165-173.

[9] Churkina, G. (2016): The role of urbanization in the global carbon cycle. - Frontiers in Ecology and Evolution 3: 144.

[10] De Ronde, J. A., Cress, W. A., Krüger, G. H. J., Strasser, R. J., Van Staden, J. (2004): Hotosynthetic response of transgenic soybean plants, containing an arabidopsis p5cr gene during heat and drought stress. - Journal of Plant Physiology 161: 1211-1224.

[11] Dewanto, V., Wu, X., Adom, K. K., Liu, R. H. (2002): Thermal processing enhances the nutritional value of tomatoes by increasing total antioxidant activity. - Journal of Agricultural and Food Chemistry 50: 3010-3014.

[12] Dzung, N. (2005): Application of chitin, chitosan and their derivatives for agriculture in vietnam. - Journal of Chitin Chitosan 10: 109-113.

[13] Elieh-Ali-Komi, D., Hamblin, M. R. (2016): Chitin and chitosan: production and application of versatile biomedical nanomaterials. - International Journal of Advanced Research 4: 411-427.

[14] Elsheery, N. I., Cao, K.-F. (2008): Gas exchange, chlorophyll fluorescence, and osmotic adjustment in two mango cultivars under drought stress. - Acta Physiologiae Plantarum 30: 769-777.

[15] Grieve, C., Grattan, S. (1983): Rapid assay for determination of water soluble quaternary ammonium compounds. - Plant and Soil 70: 303-307.

[16] Guan, Y.-J., Hu, J., Wang, X.-J., Shao, C.-X. (2009): seed priming with chitosan improves maize germination and seedling growth in relation to physiological changes under low temperature stress. - Journal of Zhejiang University Science 10: 427-433.

[17] Guidi, L., Lo Piccolo, E., Landi, M. (2019): Chlorophyll fluorescence, photoinhibition and abiotic stress: does it make any difference the fact to be a c3 or c4 species? Frontiers in Plant Science 10: 174

[18] Hazra, P., Rout, A., Roy, U., Nath, S., Roy, T., Dutta, R., Acharya, S., Mondal, A. (2003): Characterization of brinjal (Solanum melongena L.) germplasm. - Vegetable Science 30: 145-149.

[19] Ihsan, M. Z., El-Nakhlawy, F. S., Ismail, S. M., Fahad, S. (2016): Wheat phenological development and growth studies as affected by drought and late season high temperature stress under arid environment. - Frontiers in Plant Science 7: 795.

[20] IPCC (2014): Climate Change 2014 - Impacts, Adaptation and Vulnerability: Regional Aspects. - Cambridge University Press, Cambridge, UK.

[21] Jiao, Z., Li, Y., Li, J., Xu, X., Li, H., Lu, D., Wang, J. (2012): Effects of exogenous chitosan on physiological characteristics of potato seedlings under drought stress and rehydration. - Potato Research 55: 293-301.

[22] Katiyar, D., Hemantaranjan, A., Singh, B. (2015): Chitosan as a promising natural compound to enhance potential physiological responses in plant: a review. - Indian Journal of Plant Physiology 20: 1-9. 
[23] Kehoe, D. M. (2010): Chromatic adaptation and the evolution of light color sensing in cyanobacteria. - Proceedings of the National Academy of Sciences 107: 9029-9030.

[24] Kuhlgert, S., Austic, G., Zegarac, R., Osei-Bonsu, I., Hoh, D., Chilvers, M. I., Roth, M. G., Bi, K., TerAvest, D., Weebadde, P. (2016): Multispeq Beta: a tool for large-scale plant phenotyping connected to the open photosynq network. - Royal Society Open Science 3: 160592.

[25] Landi, L., De Miccolis Angelini, R. M., Pollastro, S., Feliziani, E., Faretra, F., Romanazzi, G. (2017): Global transcriptome analysis and identification of differentially expressed genes in strawberry after preharvest application of benzothiadiazole and chitosan. - Frontiers in Plant Science 8: 235.

[26] Lobell, D. B., Asner, G. P. (2003): Climate and management contributions to recent trends in U.S. agricultural yields. - Science 299: 1032.

[27] Malerba, M., Cerana, R. (2016): Chitosan effects on plant systems. - International Journal of Molecular Sciences 17: 996.

[28] Mgbemene, C. A., Nnaji, C. C., Nwozor, C. (2016): Industrialization and its backlash: focus on climate change and its consequences. - Journal of Environmental Science and Technology 9: 301-316.

[29] Myers, S. S., Smith, M. R., Guth, S., Golden, C. D., Vaitla, B., Mueller, N. D., Dangour, A. D., Huybers, P. (2017): Climate change and global food systems: potential impacts on food security and undernutrition. - Annual Review of Public Health 38: 259-277.

[30] Pandit, M., Thapa, H., Akhtar, S., Hazra, P. (2010): Evaluation of brinjal genotypes for growth and reproductive characters with seasonal variation. - Journal of Crop and Weed 6: 31-34.

[31] Ranil, R. H. G., Prohens, J., Aubriot, X., Niran, H. M. L., Plazas, M., Fonseka, R. M., Vilanova, S., Fonseka, H. H., Gramazio, P., Knapp, S. (2017): Solanum insanum L. (subgenus Leptostemonum Bitter, Solanaceae), the neglected wild progenitor of eggplant (S. melongena L.): a review of taxonomy, characteristics and uses aimed at its enhancement for improved eggplant breeding. - Genetic Resources and Crop Evolution 64: $1707-1722$.

[32] Rasul, G. (2016): Managing the food, water, and energy nexus for achieving the Sustainable Development Goals in South Asia. - Environmental Development 18: 14-25.

[33] Rochaix, J.-D. (2011): Regulation of photosynthetic electron transport. - Biochimica et Biophysica Acta (BBA)-Bioenergetics 1807: 375-383.

[34] Safikhan, S., Khoshbakht, K., Chaichi, M. R., Amini, A., Motesharezadeh, B. (2018): Role of chitosan on the growth, physiological parameters and enzymatic activity of milk thistle (Silybum marianum (L.) Gaertn.) in a pot experiment. - Journal of Applied Research on Medicinal and Aromatic Plants 10: 49-58.

[35] Salachna, P., Zawadzińska, A. (2014): Effect of chitosan on plant growth, flowering and corms yield of potted freesia. - Journal of Ecological Engineering 15: 3.

[36] Schortemeyer, M., Stamp, P., Feil, B. (1997): Ammonium tolerance and carbohydrate status in maize cultivars. - Annals of Botany 79: 25-30.

[37] Sharif, R., Mujtaba, M., Ur Rahman, M., Shalmani, A., Ahmad, H., Anwar, T., Tianchan, D., Wang, X. (2018): The multifunctional role of chitosan in horticultural crops - a review. - Molecules (Basel, Switzerland) 23: 872.

[38] Shehata, S. A., Fawzy, Z., El-Ramady, H. (2012): Response of cucumber plants to foliar application of chitosan and yeast under greenhouse conditions. - Australian Journal of Basic and Applied Sciences 6: 63-71.

[39] Sonoike, K. (2011): Photoinhibition of photosystem I. - Physiologia Plantarum 142: 5664.

[40] Teixeira, E. I., Fischer, G., van Velthuizen, H., Walter, C., Ewert, F. (2013): Global hotspots of heat stress on agricultural crops due to climate change. - Agricultural and Forest Meteorology 170: 206-215. 
[41] Walters, R. G. (2005): Towards an understanding of photosynthetic acclimation. Journal of Experimental Botany 56: 435-447.

[42] Wise, R., Olson, A., Schrader, S., Sharkey, T. (2004): Electron transport is the functional limitation of photosynthesis in field-grown Pima coton plants at high temperature. Plant, Cell \& Environment 27: 717-724.

[43] Zhang, X., Wollenweber, B., Jiang, D., Liu, F., Zhao, J. (2008): Water deficits and heat shock effects on photosynthesis of a transgenic Arabidopsis thaliana constitutively expressing ABP9, a bZIP transcription factor. - Journal of Experimental Botany 59: 839848.

[44] Zhao, J., Zhang, X., Wollenweber, B., Jiang, D., Liu, F. (2008): Water deficits and heat shock effects on photosynthesis of a transgenic Arabidopsis thaliana constitutively expressing ABP9, a bZIP transcription factor. - Journal of Experimental Botany 59: 839848. 